\title{
ばね限界值試験に関する研究委員会報告*
}

\author{
ばね限界值試験に関する研究委員会
}

\section{The Research Committee Report of the Spring Elastic Limit Test}

\author{
The Spring Elastic Limit Test Research Committee
}

\begin{tabular}{|c|c|c|}
\hline 委員 長 & 大和田哲也 & 日本金属侏) \\
\hline 副委員長 & 伊藤 健郎 & 日本ベルパーツ(侏) \\
\hline 員 & 山田 & 中央発条工業(株) \\
\hline " & 藤澤 一芳 & (株住友金属直江津 \\
\hline " & 小林 茂夫 & 株昭和試験機製作所 \\
\hline " & 今井 辰芳 & (株アドバネクス \\
\hline ブザーバ & 國峯 辰雄 & 日本ベルパーツ(株) \\
\hline
\end{tabular}

\begin{tabular}{|c|c|c|c|}
\hline 員 & 西畑 & 玉樹男 & 日本ベルパーツ(陎) \\
\hline " & 平田 & 茂 & 日本治金工業(侏) \\
\hline " & 土屋 & 司 & (株特殊金属エクセル \\
\hline " & 池澤 & 守 & 日本金属工業(株) \\
\hline " & 荒瀬 & 昇 & (有)テストロニクス \\
\hline " & 冨村 & 宏紀 & 日新製鋼(株) \\
\hline
\end{tabular}

The committee members conducted the research of spring elastic limit for spring materials. Those testing instruments used in this research were APT type tester, Siemens tester and a newly developed prototype tester. The first two traditional testers are the possessions of member companies. The measurement by APT type and Siemens tester were in good correlation. The prototype tester displayed almost equal level reading with Siemens tester as far as the spring elastic limit is concerned. Modulus of elasticity reading by the prototype tester, however, were 10 $20 \mathrm{GPa}$ higher than Siemens tester reading. The newly developed prototype tester has capability for the display of load-deflection diagram of thin specimen down to $0.05 \mathrm{~mm}$ as well as measuring spring elastic limit.

Key Words: Spring elastic limit, APT type tester, Siemens tester, Load-deflection diagram, Modulus of elasticity

\section{1. 緒言}

リレー，スイッチ，コネクタなどの電気・電子部品には 数多くの薄板ばねや細線ばねが用いられている，薄板のば ね性を評価する試験としては, 引張試験による応力ーひず み線図（降伏点，耐力，ヤング率）が多く知られるところ であるが，使用状況に即した考え方としては，ばねのへた り性を考慮した評価をすることが適していると考えられる。 ばねのへたり（永久変形）を評価する方法としては，ばね 限界值試験が簡便な評価法であり，薄板ばねの実使用にお いて広く適用されているものである。

ばね限界值試験は，1950年代にドイツから導入され，JIS 規格にも片持ちはり方式の繰り返したわみ試験とモーメン
卜式試験が定められている.

これより，今回は，ばね限界值の試験機，試験方法にお いて新しい試みとして曲げ応力（荷重）一たわみ（変位）線 図が記録できる試験機を試作した。

今回，このような試験機を製作に至ったわけだが，今後 のばね限界值の評価において新しい材料の研究, 開発に役 立つことが期待される。

\section{2. ばね限界值試験の歴史}

リレー,スイッチ，コネクタなどには，種々な目的で数 多くの薄板ばねや細線ばねが用いられている。薄板ばねは, 曲げ応力を与えて使用されることがほとんどであり，この 
曲げ応力によって生じる永久変形すなわち “へたり”が問 題となる。ばねのへたり性を評価する方法は各種行われて いるが，JIS，DIN等に規格化されている「ばね限界值試験」 が一般的である。ばね限界值試験は，ドイツのSiemens 社 が通信機器用薄板ばねのばね特性評価法として提案したも ので，我が国では，1950年前後に通信機用洋白㧍よびりん 青銅薄板ばねの試験に取り入れられた。

ばね限界值は一種の永久ひずみ応力で, 次のように定義 ${ }^{1,2)}$ されている。「ばね限界值とは，曲げによる表面最大応力が $3.675 \times \mathrm{E} / 10^{4} \mathrm{MPa}$ となるときの弾性変形と同等の永久変形 を生じさせる表面最大応力とする.」ここで，Eは，材料力

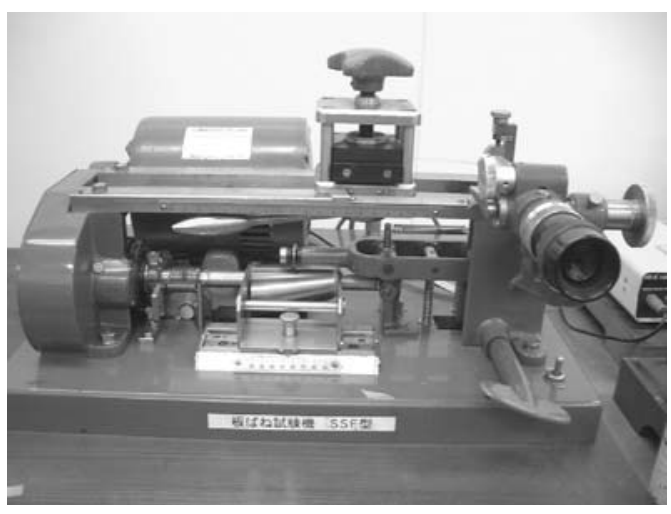

Fig. 1 Alternative bending tester (SSF type).

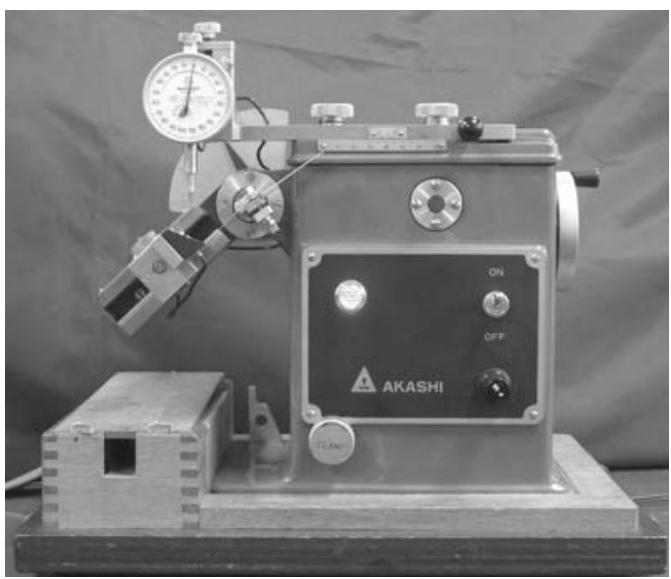

Fig. 2 Moment type tester (APT type).

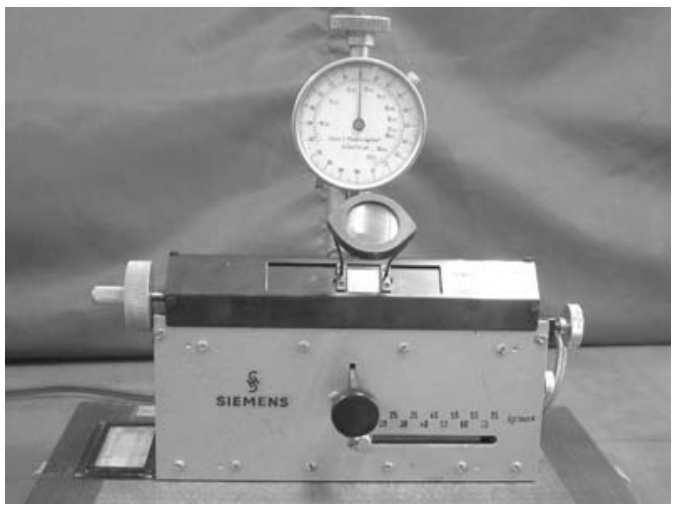

Fig. 3 Central loading type tester (Siemens type).
学上のヤング率と同等であるがJISの繰返したわみ試験の項 目で「たわみ係数」と呼んでいるので本報告では以下「た わみ係数」という。現在，ばね限界值規格と試験法は，JIS では，JIS H 3130ばね用ベリリウム銅，りん青銅及び洋白の 板及び条とJIS G 4313ばね用ステンレス鋼帯に適用されてい る。ばね限界值試験は，JISでは片持はり方式によるFig. 1に 示す繰返したわみ式試験とFig. 2に示すモーメント式試験, DINではFig. 3に示す2点支持の中央負荷方式（DIN 50151） が規格化されている。いずれの試験も試験片に曲げ変形を 与え，規定の永久たわみが生じた時点の表面最大応力を “ばね限界值”として求めるものである.

\section{3. ばね限界値試験の共同実験}

\section{1 試料と試験方法}

試料は，冷間圧延加工後TA（Tension annealing）処理を 施した板厚 $0.30 \mathrm{~mm}$ の薄板ばね用ステンレス鋼SUS301HTA とSUS304HTAを用いた，その化学成分をTable 1，ビッカー 久硬さと引張強さをTable 2に示す。ばね限界值試験片加工 は，各社（5社）にて行い，その採取方向は，圧延方向と平 行方向（以下 $0^{\circ}$ 方向と略す）とした.

ばね限界值測定は，各社保有のモーメント式試験機（以 下APT型と略す）を用い，その試験条件（試験片寸法，又 パン長，応力負荷時間）をTable 3に示す。なお，一社のみ 中央負荷方式試験機（以下シーメンス型と略す）でも測定 を行った。ここで，試験片の反り方向は，試験片を定盤に 置いたとき左右端部に対して中央部が上に凸になる曲がり 形状の場合を上反り，その逆の曲がり形状の場合を下反り と定義した。

Table 1 Chemical composition of the specimens.

\begin{tabular}{|l|c|c|c|c|c|c|c|}
\hline \multirow{2}{*}{ Specimen } & \multicolumn{7}{|c|}{ Chemical composition (mass \%) } \\
\cline { 2 - 8 } & $\mathrm{C}$ & $\mathrm{Si}$ & $\mathrm{Mn}$ & $\mathrm{P}$ & $\mathrm{S}$ & $\mathrm{Ni}$ & $\mathrm{Cr}$ \\
\hline SUS301HTA & 0.10 & 0.66 & 0.98 & 0.027 & 0.005 & 6.90 & 16.97 \\
\hline SUS304HTA & 0.06 & 0.42 & 0.83 & 0.029 & 0.003 & 8.20 & 18.01 \\
\hline
\end{tabular}

Table 2 Tensile strength and micro-vickers hardness of the specimens.

\begin{tabular}{|l|c|c|}
\hline Specimen & Hradness $(\mathrm{HV})$ & Tensile strength (MPa) \\
\hline SUS301HTA & 460 & 1500 \\
\hline SUS304HTA & 380 & 1130 \\
\hline
\end{tabular}

Table 3 Conditions of spring elastic limit testing.

\begin{tabular}{|c|c|c|c|c|}
\hline Supplier & Tester & $\begin{array}{c}\text { Test piece size } \\
(\mathrm{mm})\end{array}$ & $\begin{array}{c}\text { Span : L } \\
(\mathrm{mm})\end{array}$ & $\begin{array}{c}\text { Loading } \\
\text { (sec.) }\end{array}$ \\
\hline A & \multirow{5}{*}{ APT } & Width: 10 , Length: Span +30 & $\mathrm{~L}^{2} / \mathrm{t}=3000$ & \multirow{6}{*}{5} \\
\hline B & & Width:10, Length: 100 & $\mathrm{~L}^{2} / \mathrm{t}=4000$ & \\
\hline $\mathrm{C}$ & & Width:10, Length: 120 & $\mathrm{~L}^{2} / \mathrm{t}=3000$ & \\
\hline $\mathrm{D}$ & & Width: 10 , Length: 100 & $\mathrm{~L}^{2} / \mathrm{t}=4000$ & \\
\hline $\mathrm{E}$ & & Width: 10 , Length: 100 & $\mathrm{~L}^{2} / \mathrm{t}=4000$ & \\
\hline $\mathrm{B}$ & Siemens & Width: 10 , Length: 100 & $\mathrm{~L}^{2} / \mathrm{t}=8000$ & \\
\hline
\end{tabular}

t:Thickness 
APT型とシーメンス型測定における試験片上反り，下反 り形状のセットと曲げ荷重負荷方向状態をFig. 4に示す.

\section{4. 共同実験結果}

試料SUS301HTA，SUS304HTAの上反り，下反りのAPT型 によるばね限界值測定の共同実験結果を整理LFig. 5に示す。

Fig. 5 (a)（b）から各社の平均值はSUS301HTAでは，上 反り：676〜753MPa，下反り：792〜856MPaとなった。全 社の平均值での比較では, 上反りは $715 \mathrm{MPa}$, 下反りは $826 \mathrm{MPa}$ となり上反りは下反りよりも $110 \mathrm{MPa}$ 程度低い值を 示した。これは, 試験片の反り量の大きさが原因である. SUS304HTAは，上反り：708〜 774MPa，下反り：696〜 759MPaとなった。このようにSUS304HTAでは，平坦度が 良好であったため上反り下反りの差が $10 \mathrm{MPa}$ 程度と非常に 少なかった。

共同実験結果から, 各社の值の差異はあるが平均值で比 較するとバラッキは, 両試料とも60～80MPa程度となり， ほぼ同一水準の值が得られていることが認められた。

\section{5. 委員会で試作したばね限界値試験機}

\section{1 基本構成と試作}

$\mathrm{JIS} ， \mathrm{DIN}^{3)}$ に規格されているばね限界值試験機を検討し， 実用性，操作性，経済性等を考慮して新ばね限界值試験機 の構成を決定した。また，ばね限界值については，従来の 定義を採用した。

本試験機の基本構成を以下に示す.

(1)曲げ荷重負荷は，Fig. 6に示すように中央負荷方式を採 用.ここで, $\mathrm{t}$ ：試料板厚, $\mathrm{b}$ : 試料幅, $\mathrm{W}$ ：曲げ荷重, $\mathrm{L}$ ：スパン, $\mathrm{F}$ ：変位（たわみ量）である。また，中央 負荷方式試験での $\mathrm{t}$ と関係と永久たわみの関係を Table 4に示す.

(2)曲げ荷重は，ロードセルにて検出.

(3)曲げ変位量は, 光学变位測定計（レーザー变位計）に て検出.

(4)曲げ変位は駆動シリンダによる自動負荷.

(5)曲げ荷重一変位線図の自動作成を行う.

(1回目と設定永久たわみ量が計測される前後の線図)

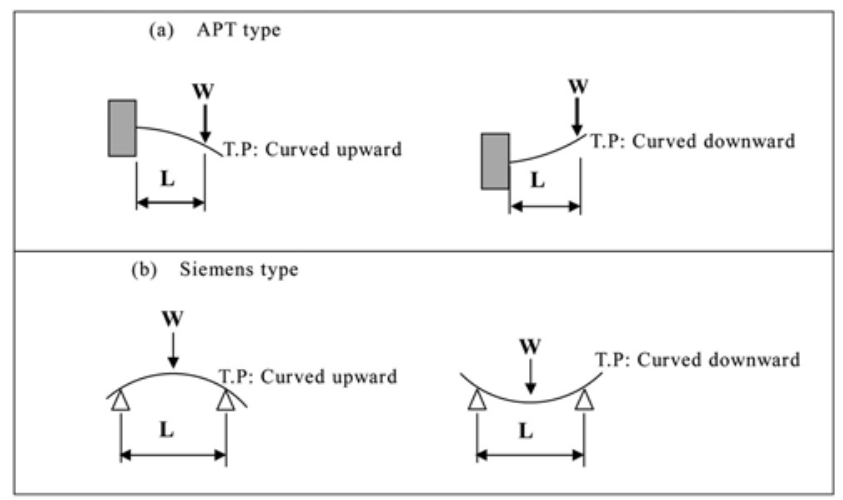

Fig. 4 The principle of loading in the testing apparatus.
(6)ばね限界值は, 試料寸法 (板厚, 板幅), スパン長, た わみ係数, 永久たわみ量の入力することにより自動計算. (7)試験片寸法は, 幅 $10 \mathrm{~mm}$, 長さ $100 \mathrm{~mm}$ の短冊形状.

以上の基本を考慮し本委員会で製作したばね限界值試験機 の外観と試験片をセットした状態の拡大写真をFig. 7に示す.

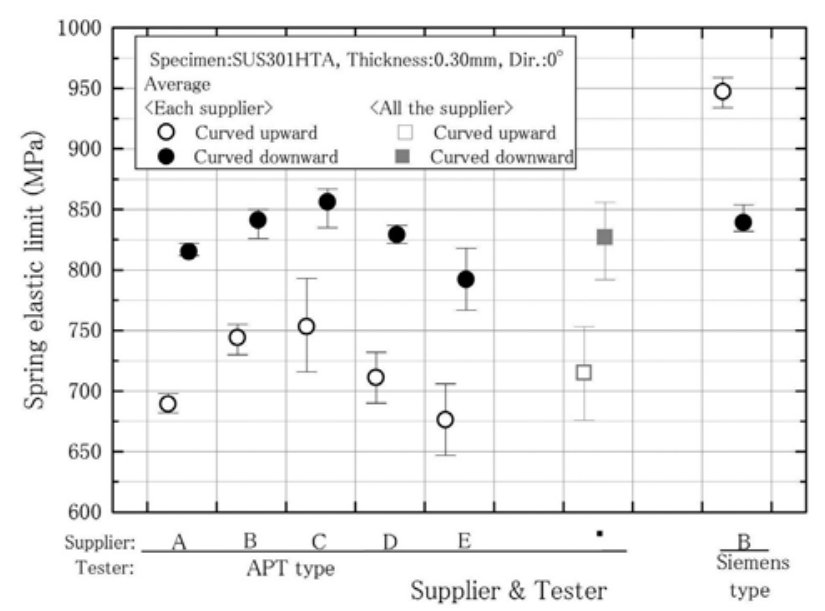

(a) SUS301HTA.

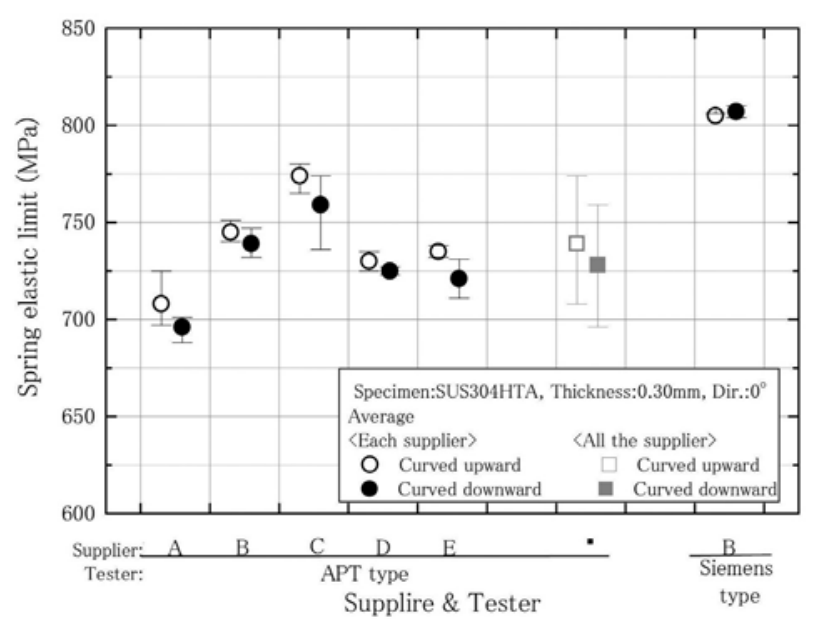

(b) SUS304HTA.

Fig. 5 Results of the spring elastic limit tests of thin stainless steel plates in individual supplier (Specimen:SUS301HTA,SUS304HTA, Supplier : A, B $\cdots$ E, Plot : Average).
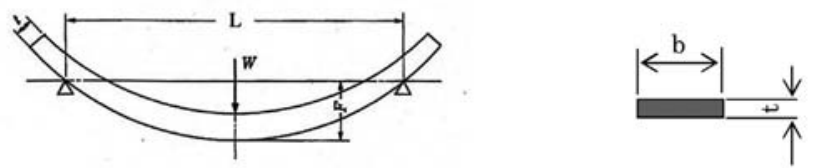

Fig. 6 Measurement principle of the central loading type tester.

Table 4 Relations between measurement condition and the eternal bend.

\begin{tabular}{|c|c|c|}
\hline Measurement condition: $\mathrm{L}^{2} / \mathrm{t}$ & 8000 & 4000 \\
\hline Permanent set $: \mathrm{F}(\mathrm{mm})$ & 0.05 & 0.025 \\
\hline
\end{tabular}




\section{6. 実験結果}

試料は，板厚 $0.05 \sim 0.30 \mathrm{~mm}$ の薄板ばね用ステンレス鋼 SUS304H抢よびSUS304HTA材である。また，銅合金ばね材 料として板厚 $0.20 \mathrm{~mm} の \mathrm{Cu}-\mathrm{Ni}-\mathrm{Sn}$ 合金NB109とりん青銅㧍よ び板厚 $0.10 \mathrm{~mm}$ のばね用りん青銅を用いた。試験片の寸法は, 幅 $10 \mathrm{~mm}$, 長さ $100 \mathrm{~mm}$ で, 試料の採取方向は $0^{\circ}$ 方向である.

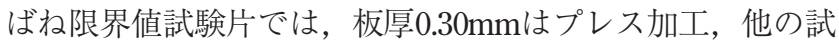
料はフォトエッチング加工により製作した。まず，本試作 機で各試料のばね限界值とたわみ係数の測定を行った。っ いで，従来のAPT型，シーメンス型試験機にて同様の測定 を行った。そのばね限界值測定結果をFig. 8, たわ久係数測 定結果をFig. 9に示す。本試験機のばね限界值測定方法では,

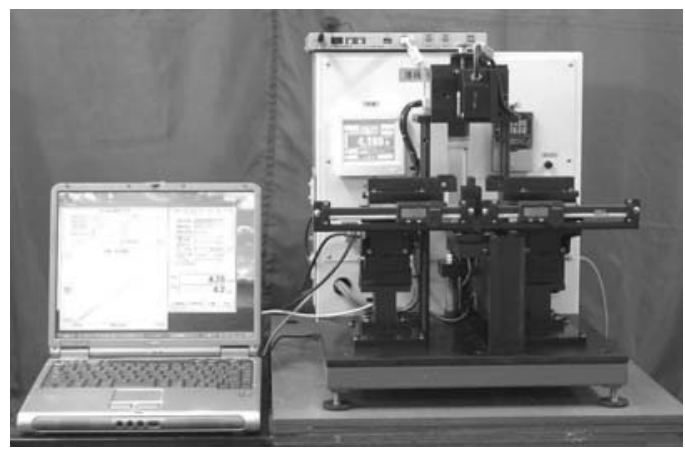

(a) Overview.

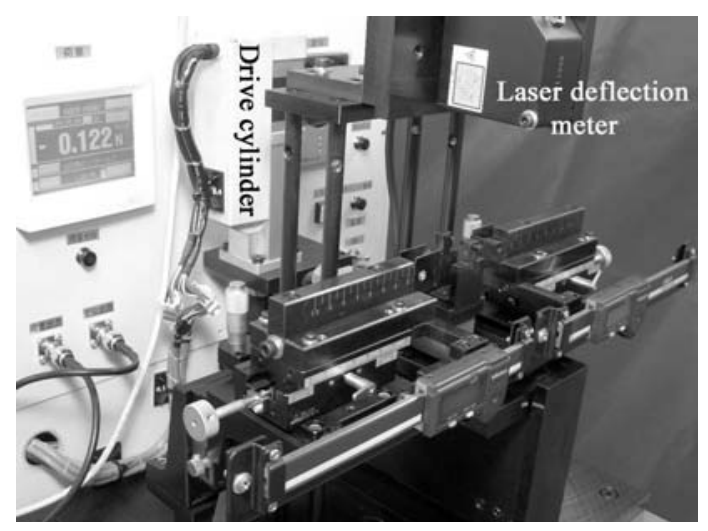

(b) A close-up of measuring apparatus.

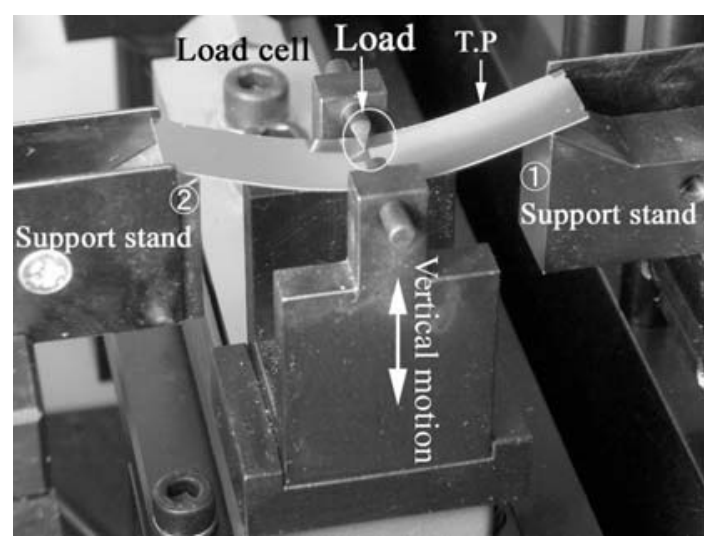

(c) the test piece set-up for the test.

Fig. 7 A central loading type testing apparatus to measure spring elastic limit of thin plates developed in the committee.
予め，試料のたわみ係数を求める必要がある。その，たわ み係数：Eの測定は，スパンは試験片板厚の100倍, 曲げ荷 重0.1〜2Nの範囲で試験片に負荷した曲げ荷重と変位量の実 測值から算出した。

Fig. 8の測定結果から各試料のばね限界值は, 若干の差異 はあるが測定原理が同一のシーメンス型とほぼ同一水準の 值が得られた。また，本試作機は，従来の試験機では測定 不可能であった板厚 $0.08,0.05 \mathrm{~mm}$ の測定も行いばね限界值 を求めた．Fig. 9の測定結果から本試作機のたわみ係数值は, シーメンス型より 10～20GPa程度高い值を示した。さらに， 本試験機で得られた「曲げ荷重一変位」線図の一例をFig. 10 （a，b，c，d，e）に示す。この線図は，従来の試験機では 得られなかった線図であり，今後，薄板ばね材料の曲げ特 性評価やオフセット法にてばね限界值を新定義する案の一 つになると思われる。

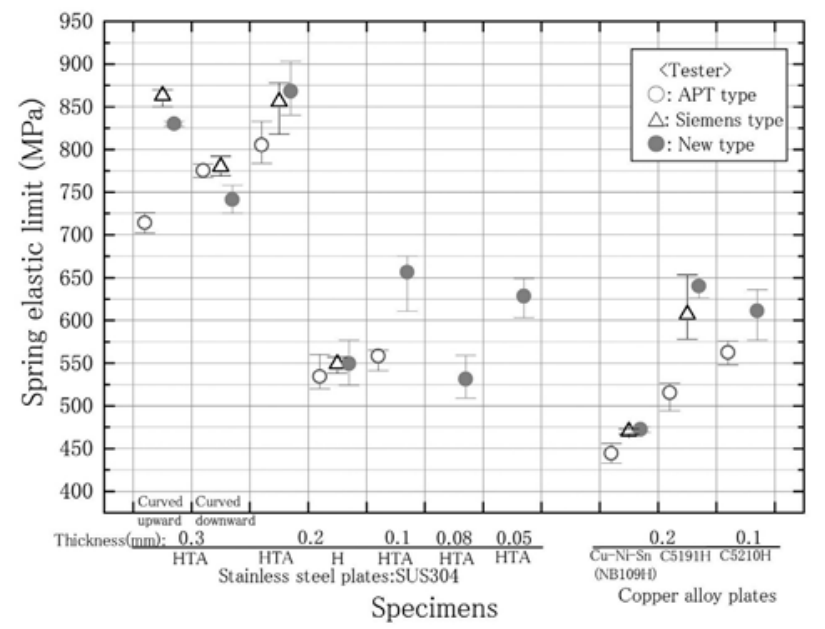

Fig. 8 The result of spring elastic limit measured by conventional and the new methods.

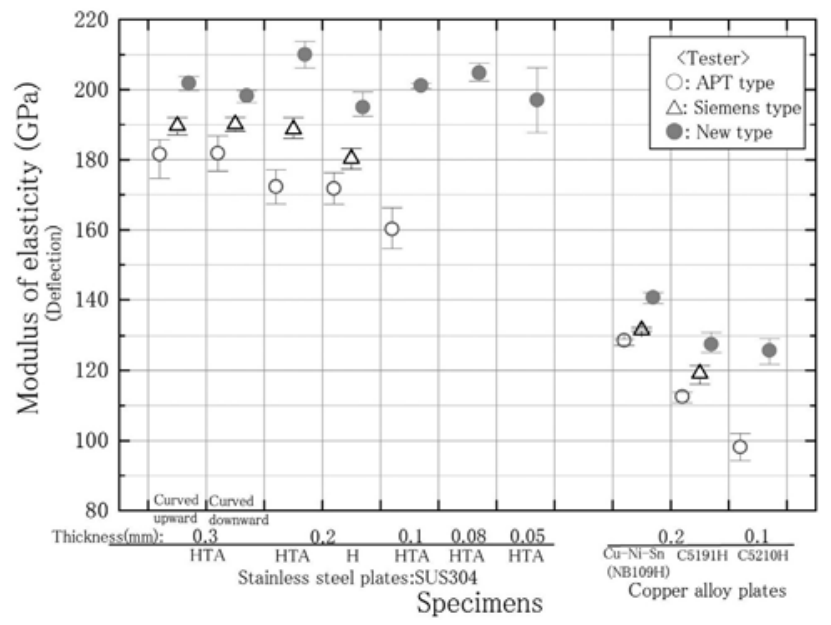

Fig. 9 The result of modulus of elasticity measured by conventional and the new methods. 


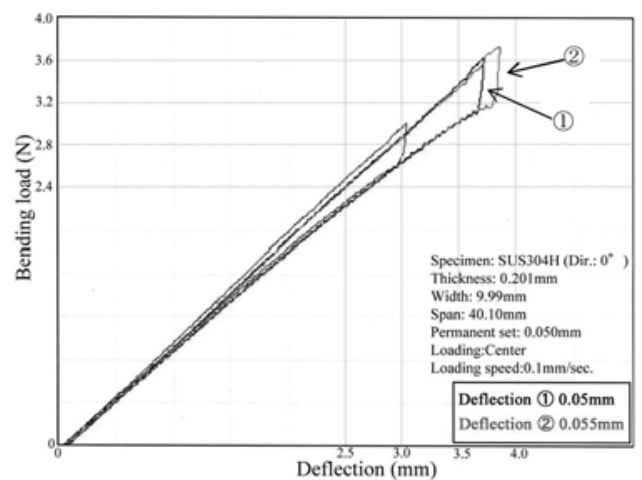

(a) SUS304H.

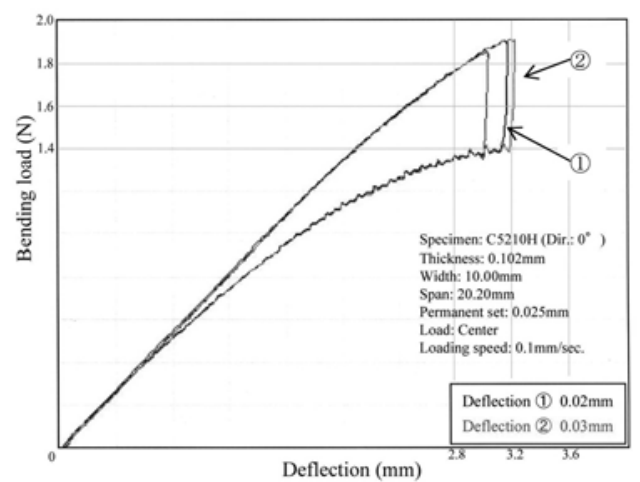

(c) $\mathrm{C} 5210 \mathrm{H}$.

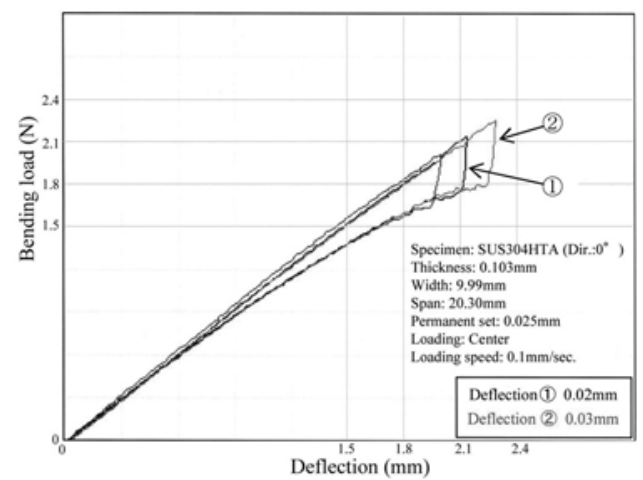

(b) SUS304HTA.

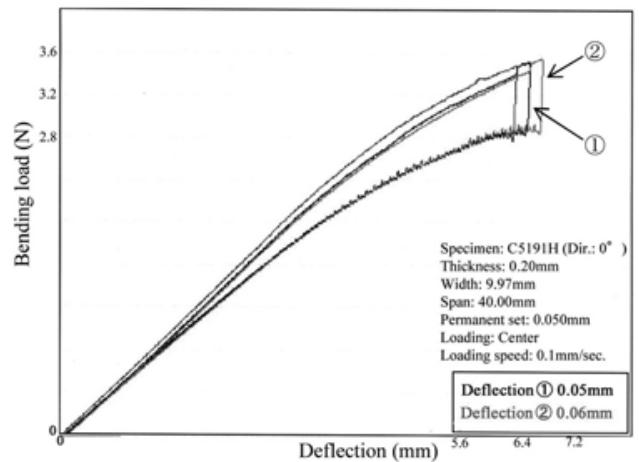

(d) $\mathrm{C} 5191 \mathrm{H}$.

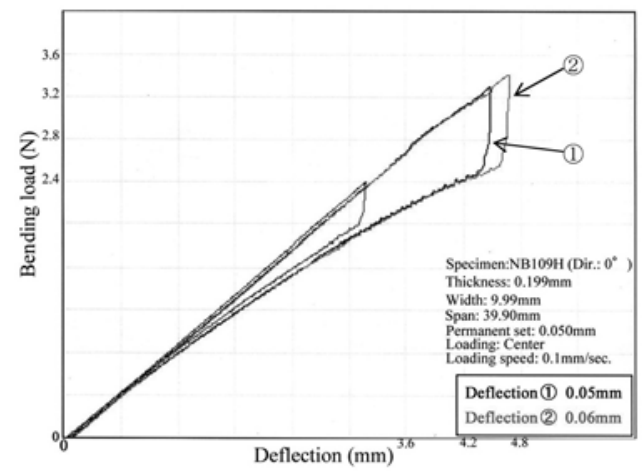

(e) NB109H.

Fig. 10 Load-deflection diagrams of very thin spring plates with different material.

\section{7. まとめ}

本委員会では，新ばね限界值試験機を製作し，板厚 0.05 〜0.3mmのステンレス鋼と銅合金のばね材料を用い，ばね 限界值，たわみ係数の測定を行い，従来のばね限界值試験 機との比較を行った。その試験で得られた結果は次のよう に要約される。

（1）ばね限界值はシーメンス型とほぼ同一水準の值が得ら れた。

（2）たわみ係数はシーメンス型より 10～20GPa程度高い值 であった。

(3) 従来試験機では測定不可能であった板厚 $0.1 \mathrm{~m}$ 以下の測 定ができた。
（4）従来試験機では得られなかった「曲げ何重 - 変位」線 図を得る事ができた。

今後，本委員会で試作した新ばね限界值試験機の有効性 をさらに検討し，実用化を図る必要があると考えられる。

\section{参考文献}

1）横井, 荒井, 徳岡, 日本機械学会誌, Vol.70, No.584, (1967) PP.1348 - 1352.

2）三島, 真下, 岩崎, 日本機械学会誌, Vol.72, No.601, (1969) PP.246 - 250.

3) DIN EN 12384 (1999). 